Tadeusz Kałużny SCJ1

0000-0002-3902-2931

Uniwersytet Papieski Jana Pawła II w Krakowie

\title{
Ku ekumenii realistycznej. W poszukiwaniu przyczyn trudności w katolicko-prawosławnym dialogu teologicznym
}

Wśród dialogów bilateralnych Kościoła rzymskokatolickiego katolicko-prawosławny dialog teologiczny na forum światowym należy niewątpliwie do najważniejszych i budzących wielką nadzieję. Wynika to przede wszystkim z doktrynalnej bliskości między katolicyzmem i prawosławiem, jak też praktycznego uznania przez obie strony dialogu tych elementów, które przynależą do istotnej struktury Kościoła. Wbrew pozorom nie jest to jednak dialog łatwy. W swojej blisko czterdziestoletniej historii przeżywał on zarówno chwile entuzjazmu, jak i kryzysu. Mimo niewątpliwych osiągnięć, dialog ten wciąż boryka się z wieloma

1 Tadeusz Kałużny SCJ - sercanin, dr hab., prof. UPJPII; kierownik Katedry Ekumenizmu Wydziału Teologicznego Uniwersytetu Papieskiego Jana Pawła II w Krakowie; wykładowca teologii dogmatycznej i ekumenizmu w Wyższym Seminarium Misyjnym Księży Sercanów w Stadnikach. E-mail: tadeusz.kaluzny@upjp2.edu.pl. 
trudnościami. Celem niniejszej refleksji jest próba ukazania ważniejszych przyczyn trudności katolicko-prawosławnego dialogu teologicznego.

Prezentowany temat zostanie rozwinięty w czterech częściach. Na początku zwrócimy uwagę na odmienną świadomość podziału w katolicyzmie i w prawosławiu. Następnie dokonamy ogólnej prezentacji wybranych aspektów „dialogu miłości” i „dialogu prawdy”. W trzeciej części omówimy uwarunkowania początków katolicko-prawosławnego dialogu teologicznego. W końcu odniesiemy się do kluczowych problemów natury eklezjologicznej, które determinują omawiany dialog.

\section{1. Świadomość podziału}

Rozbieżności między katolikami i prawosławnymi pojawiają się już w interpretacji podziału, jaki dokonał się w XI wieku między chrześcijańskim Wschodem i Zachodem.

\subsection{Ocena przyczyn i skutków podziału}

Sobór Watykański II odniósł się do sprawy przyczyn podziału jedynie w sposób ogólny, pomijając bardziej szczegółową ocenę konkretnych faktów historycznych. W soborowym Dekrecie o ekumenizmie Unitatis redintegratio stwierdza się, że zerwanie jedności między Wschodem i Zachodem, poza różną mentalnością, odmiennymi warunkami życia i niektórymi innymi przyczynami zewnętrznymi, było spowodowane także „brakiem wzajemnego zrozumienia i miłości”. W konsekwencji po soborze watykańskim II strona katolicka kieruje się w dialogu

\footnotetext{
${ }^{2}$ Sobór Watykański II, Dekret o ekumenizmie „Unitatis redintegratio”, 21 listopada 1964 (dalej: UR), nr 14. Bardzo ogólne odniesienia do tej kwestii znajdujemy również w nr 3 i 13 Dekretu o ekumenizmie. Tak np. w nr 3 dokumentu stwierdza się między innymi: „W następnych zaś wiekach zrodziły się jeszcze większe spory i doszło do odłączenia się niemałych Wspólnot od pełnej jedności (communio) z Kościołem katolickim, często nie bez winy ludzi z jednej i drugiej strony".
} 
z prawosławnymi duchem otwartości, uwydatniając to, co łączy obydwie strony, zgodnie z powiedzeniem: „szklanka do połowy pełna”.

W tym samym czasie strona prawosławna, zwłaszcza w kontekście dyskusji wewnątrzprawosławnych, starała się i nadal stara ostudzić katolicki optymizm, podkreślając, że przyczyny podziału z XI wieku są bardzo poważne i w rzeczywistości nadal istnieją. W rezultacie, strona prawosławna zdaje się akcentować w relacjach $\mathrm{z}$ katolikami to, co dzieli obydwie strony. W swoim podejściu do badanej kwestii prezentuje więc wizję: „szklanka do połowy pusta”. Takie stanowisko zostało sformułowane, dla przykładu, w dokumencie Soboru Biskupów Kościoła rosyjskiego: Podstawowe zasady dotyczące stosunku Rosyjskiego Kościoła Prawosławnego do nieprawosławnych (2000) ${ }^{4}$. W tekście tym wyrażono przekonanie, że wszystkie podziały, włącznie z tym z 1054 roku, były odejściem od prawdziwego Kościoła Chrystusa, którym pozostaje Kościół prawosławny ${ }^{5}$. Autorzy dokumentu odrzucają jednocześnie pogląd, że przyczyną podziałów były sprawy drugorzędne, czynniki nieteologiczne: ludzki egoizm lub też kulturowe, społeczne bądź polityczne uwarunkowania. Rozłam świata chrześcijańskiego jest bowiem rozłamem w samym doświadczeniu wiary ${ }^{6}$. W tym samym kierunku zmierza dokument Kreteńskiego Soboru Relacje Kościoła prawosławnego z pozostałym światem chrześcijańskim (2016) ${ }^{7}$. Autorzy dokumentu zdają się przy tym utrzymywać, że podział chrześcijaństwa jest wynikiem błędów wyłącznie innych

3 Por. L. Žak, Il cammino ecumenico aperto da „Unitas redintegratio” tra difficoltà e speranze: in dialogo con l'ortodossia, „Lateranum” 81 (2015) nr 2, s. 464-465.

4 Por. Архиерейский Собор Русской Православной Церкви, Основные принцииы отношения Русской Православной Церкви к инославию (2000), „Журнал Московской Патриархии" $2000 \mathrm{nr}$ 10, s. 22-30.

5 Рor. Архиерейский Собор Русской Православной Церкви, Основные принц̧ипы отношения Русской Православной Церкви к инославию (2000) nr 1.1 oraz 1.13.

6 Por. Архиерейский Собор Русской Православной Церкви, Основные принцииы отношения Русской Православной Церкви к инославию (2000) nr 2.6; 2.8; 2.10; 2.11.

7 Por. Saint et grand Concile de l'Église orthodoxe, Les relations de l'Église orthodoxe avec l'ensemble du monde chrétiens (Crète, 2016), w: The Great Councils of the Orthodox Churches. Decisions and Synodika, ed. A. Melloni, Brepols 2016, s. 1253-1293 (Corpus Christianorum Conciliorum Oecumenicorum Generaliumque Decreta. Editio critica, IV. 3). 
„Kościołów” i „Wyznań”, które „odeszły” od prawdziwej wiary Kościoła prawosławnego 8 .

Kościół rzymskokatolicki i Kościoły prawosławne dokonują zatem odmiennej oceny skutków rozłamu w Kościele w XI wieku. Podczas gdy strona katolicka zasadniczo reprezentuje pogląd, że rozłam z 1054 roku był tylko schizma, która - zgodnie z poglądami katolickimi - nie oznacza odejścia od prawdziwej wiary, tzn. herezji, to strona prawosławna - mimo pewnych rozbieżności w tym względzie w łonie prawosławia - znacznie surowiej ocenia skutki rozłamu z 1054 roku. Wszystko to ma swoje implikacje dla prawosławnej oceny eklezjalnego charakteru „Kościoła” katolickiego i ważności sprawowanych w nim sakramentów9.

\subsection{Współzależność różnic historyczno-kulturowych i doktrynalnych}

Odmienna świadomość podziału kościelnego w katolicyzmie i prawosławiu wynika $\mathrm{w}$ dużym stopniu $\mathrm{z}$ odmiennego sprzężenia różnic historycznych, kulturowych i prawnych z warstwą doktrynalną w każdym z Kościołów. Obydwa Kościoły spotykają się bowiem na odmiennej płaszczyźnie kulturowej i czasowej. Podczas gdy świadomość katolicką w wymiarze doktrynalnym określa nieprzerwany rozwój dogmatów, świadomość prawosławną określa głównie dorobek siedmiu pierwszych soborów powszechnych, wspólnych dla chrześcijaństwa Wschodu i Zachodu. W ten sposób elementy historyczno-kulturowe w prawosławiu niewspółmiernie przerastają jego rozwój doktrynalny. W rezultacie w katolicyzmie występuje mniejszy stopień spójności elementów historyczno-kulturowych i doktrynalnych, natomiast w prawosławiu ta spójność jest większa. Wynika stąd szczególne przywiązanie prawosławia do tradycji/Tradycji. W prawosławiu - jak zauważył angielski obserwator, Henry Noel Brailsford (1873-1958) - wieki nie następują po sobie, one

8 Por. Saint et grand Concile de l'Église orthodoxe, Les relations de l'Église orthodoxe avec l'ensemble du monde chrétiens (Crète, 2016), dz. cyt., nr 20-21.

9 Por. Д.П. Огицкий, М. Козлов, Православие и западное христианство. Учебное пособие для духовных семинарий и духовных училищ, Москва 1999; R. Hotz, Kościót wschodni a Kościót zachodni. Dwie przeciwstawne perspektywy, „Communio” 13 (1993) nr 4, s. 65-66; T. Kałużny, Eklezjalna świadomość prawosławia a ekumenia, „Sympozjum” 11 (2007) nr 1, s. 51-66. 
współistnieją ${ }^{10}$. To powoduje, że dialog katolicko-prawosławny jest trudniejszy od innych dialogów Kościoła rzymskokatolickiego. Może o tym świadczyć historia posoborowego dialogu ekumenicznego między katolikami i prawosławnymi ${ }^{11}$.

\section{Od „dialogu miłości” do „dialogu prawdy”}

W zainicjowanym wraz z soborem watykańskim II dialogu ekumenicznym między Kościołem rzymskokatolickim a Kościołem prawosławnym można wyróżnić dwa zasadnicze etapy: 1) „dialog miłości” (1958-1979), który znajduje wyraz w licznych spotkaniach ekumenicznych i symbolicznych gestach braterskiej miłości ze strony przedstawicieli obu stron oraz 2) „dialog prawdy” lub oficjalny dialog teologiczny (1980--12.

\subsection{Teologiczne znaczenie „dialogu miłości”}

„Dialog miłości” - zgodnie z powszechnym przekonaniem obydwu stron - jest ściśle związany z „dialogiem prawdy”. Stanowi on przygotowanie i niezbędną część dialogu teologicznego. W związku z tym wszelkie próby naruszenia więzi między dialogiem miłości i dialogiem prawdy budzą w relacjach katolicko-prawosławnych zastrzeżenia i obawy. Takie naruszenie więzi - najogólniej ujmując - może dokonać się na dwa sposoby: poprzez zawężenie dialogu ekumenicznego wyłącznie do „dialogu miłości” oraz poprzez rozwijanie „dialogu prawdy” bez należytego uwzględnienia znaczenia „dialogu miłości”. W pierwszym przypadku „dialog miłości” traktowany jest jako szczyt dialogu ekumenicznego, co prowadzi do ignorowania lub relatywizowania rozbieżności w sformułowaniach wiary i ustroju Kościoła. W drugim przypadku niedocenienie

10 Na tę cechę prawosławia zwraca uwagę także polski teolog prawosławny, ks. Jerzy Klinger. Por. J. Klinger, O istocie prawosławia. Wybór pism, Warszawa 1983, s. 427-428.

11 Por. J. Jarco, Stagnacja czy postęp? Dialog katolicko-prawosławny, „Życie i Myśl” 1972 nr 11-12, s. 59.

12 Na ten temat zob. T. Kałużny, Na drogach jedności. Dwustronne dialogi doktrynalne Kościoła rzymskokatolickiego na płaszczyźnie światowej, Kraków 2012, s. 28-39. 
„dialogu miłości” sprawia, że rozwój dialogu teologicznego, jak i recepcja jego osiągnięć napotykają na swej drodze poważne trudności. Wtedy też można mówić o pewnej bezsilności obu stron, które mimo wypracowanych uzgodnień dialogowych, pozostają zbyt uwarunkowane swoją całościową sytuacją, żeby zdobyć się na obustronne decyzje ekumeniczne $\mathrm{w}$ życiu ${ }^{13}$.

W tym kontekście warto zauważyć, iż pomimo wielkiego znaczenia, jakie zasadniczo obie strony przypisują „, dialogowi miłości” i związanym z nim symbolicznym gestom na drodze wzajemnego zbliżenia, wydarzenia te nie spotykają się z jednoznaczną oceną i recepcją w obydwu Kościołach, co niewątpliwie osłabia ich znaczenie teologiczne i ekumeniczne. Od tego rodzaju „dwuznaczności” nie są wolne nawet tak doniosłe wydarzenia, jak na przykład historyczne spotkanie papieża Pawła VI i patriarchy Atenagorasa I w styczniu 1964 roku w Jerozolimie, zniesienie rok później (7 grudnia 1965 roku) ekskomunik z 1054 roku, dzięki czemu rozpoczęło się „oczyszczenie wspólnej pamięci” ${ }^{14}$, czy spotkanie papieża Franciszka z patriarchą Moskwy Cyrylem w Hawanie 12 lutego 2016 roku $^{15}$.

Spotkanie Pawła VI i Atenagorasa I w Jerozolimie wywołało wielki entuzjazm na całym Zachodzie, gdyż widziano w nim „preludium do przywrócenia jedności" między Kościołem Wschodu i Zachodu ${ }^{16}$. W Grecji zaś wzbudziło reakcje negatywne i protesty, a w kilku klasztorach na Górze Athos nawet wykreślenie imienia patriarchy Atenagorasa $z$ dyptychu. W związku z tym powoływano się między innymi na kanony apostolskie 11 i 12, które zabraniają wspólnej modlitwy ze schizmatykami

13 Por. J. Jarco, Stagnacja czy postęp..., dz. cyt., s. 60.

14 Por. Wspólna deklaracja papieża Pawła VI i patriarchy Atenagorasa I zawierajaca decyzje wymazania z pamięci i miejsca w Kościele sentencji ekskomunik z 1054 roku (Fanar, 7 grudnia 1965), w: Jan Paweł II $w$ dialogu miłości z Kościołem Wschodnim, red. A. Polkowski, Warszawa 1984 [dalej:JPwD], s. 330-331; Brewe papieża Pawła VI „Ambulate in dilectione” ogłaszajace wymazanie z pamięci i miejsca w Kościele ekskomunik z 1054 r., 7 grudnia 1965, w: JPwD, s. 332-333; „Tomos” patriarchy, w którym patriarcha Athenagoras I i zgromadzony z nim synod ogłaszaja wymazanie z pamięci i miejsca w Kościele ekskomunik z 1054 r. (Fanar, 7 grudnia 1965), w: JPwD, s. 334-335.

15 Por. Wspólna Deklaracja papieża Franciszka i patriarchy Cyryla, Hawana (Kuba), 12 lutego 2016 r., https://opoka.org.pl/biblioteka/W/WP/franciszek_i/inne/deklaracja-hawana_12022016.html (14.06.2018).

16 Por. P. Kizeridis, Il dialogo tra le Chiese cattolica e ortodossa dal 1920 all'abolizione delle scomuniche, Roma 1966, s. 93-94. 
i heretykami ${ }^{17}$. Z dużą rezerwą przyjęto też w prawosławiu decyzję o odwołaniu w 1965 roku wzajemnych ekskomunik, jakie nałożono obustronnie po wydarzeniach roku 1054 roku. Wiele Kościołów prawosławnych widziało w tym akt, który nie dotyczy całego prawosławia, ale jedynie lokalnego Kościoła w Konstantynopolu ${ }^{18}$. Wydarzenie to zostało przyjęte bardzo nieufnie zwłaszcza w Kościele prawosławnym Grecji, gdzie przez wielu zostało uznane za nieszczęście dla prawosławia ${ }^{19}$.

Z kolei po spotkaniu Cyryla z Franciszkiem 12 lutego 2016 roku pojawiło się szereg głosów krytycznych w łonie rosyjskiego Kościoła prawosławnego. Zarówno duchowni, łącznie z niektórymi biskupami, jak i wielu świeckich, zarzucało zwierzchnikowi Kościoła rosyjskiego zdradę prawosławia ${ }^{20}$. W związku z tym Wydział Zewnętrznych Stosunków Kościelnych Patriarchatu 15 kwietnia 2016 roku wydał oświadczenie, w którym odniósł się do zarzutów i wyjaśnił cel tego spotkania. Stwierdzono w nim, że celem spotkania nie było przezwyciężenie różnic między obydwoma Kościołami, a w toku spotkania nie zostały poruszone jakiekolwiek zagadnienia teologiczne czy kanoniczne ${ }^{21}$. W związku z tym na miejsce spotkania Franciszka z Cyrylem zostało wybrane pomieszczenie lotniska w Hawanie, nie niosące żadnej symbolicznej i kościelnej treści. Nawet jeśli przyjmie się, że taka organizacja i interpretacja „historycznego spotkania" w Hawanie stanowiła próbę uspokojenia środowisk ultrakonserwatywnych i antyekumenicznych $\mathrm{w}$ prawosławiu rosyjskim, to fakt ten niewątpliwie wskazuje na poważne trudności w recepcji posoborowego „dialogu miłości” w prawosławiu rosyjskim. Co więcej, jeśli

17 Por. J. Bujak, Jedność na nowo odkrywana. Dialog katolicko-prawosławny w latach 1958-2000, Poznań 2001, s. 23.

$18 \mathrm{Na}$ temat reakcji Patriarchatu Moskiewskiego zob. „Журнал Московской Патриархии" (1966) nr 2, s. 4.

19 Por. V. Martano, Athenagoras, il patriarca (1886-1972). Un cristiano fra crisi della coabitazione e utopia ecumenica, Bologna 1996, s. 477; E. Fotiju, Gdy lęk silniejszy niż nadzieja..., w: Ekumeniczna odpowiedzialność na początku Trzeciego Tysiąclecia, red. G. Górka, S. Pawłowski, Lublin 2003, s. 218.

20 Por. Burza w prawosławiu po historycznym spotkaniu, https://wiadomości.monasterujkowice.pl/?p=17699 (15.05.2018).

21 Рог. Заявление Службы коммуникации ОВЦС о встрече Патриарха Московского и всея Руси Кирилла и Папы Римского Францзиска (15.04.2016), https://mospat.ru/ru/2016/04/15/ new130222 (15.05.2018). 
każda ze stron dialogu odczytuje spotkanie Franciszka z Cyrylem „po swojemu", to rodzi uzasadnione pytanie o kościelne i ekumeniczne znaczenie tego wydarzenia ${ }^{22}$.

\subsection{Początek i rozwój dialogu teologicznego}

Posoborowy „dialog miłości”, znaczony gestami wzajemnej życzliwości i dobrej woli, pozwolił na podjęcie katolicko-prawosławnego dialogu teologicznego na forum światowym. Powołana w 1979 roku Międzynarodowa Komisja Mieszana do Dialogu Teologicznego między Kościołem rzymskokatolickim a Kościołem prawosławnym rozpoczęła pracę w 1980 roku. Podczas pierwszej sesji Komisji przyjęto Plan realizacji dialogu teologicznego pomiędzy Kościołem katolickim $i$ Kościołem prawosławnym, prezentujący cel, metodę i problematykę pierwszej fazy dialogu teologicznego ${ }^{23}$.

W dotychczasowej historii dialogu, biorąc pod uwagę jego tematykę, można wyodrębnić trzy fazy. W pierwszej fazie dialogu (1980-1990) zgodnie z przyjętym Planem - prace Komisji Mieszanej koncentrują się wokół sakramentów. Owocem tej fazy dialogu są trzy dokumenty: Misterium Kościoła i Eucharystii w tajemnicy Trójcy Świętej (Monachium, 1982) ${ }^{24}$; Wiara, sakramenty i jedność Kościoła (Bari, 1987)25; Sakrament kapłaństwa w sakramentalnej strukturze Kościoła ze szczególnym uwzględnieniem znaczenia sukcesji apostolskiej dla uświęcenia i jedności Ludu Bożego (Uusi Valamo, 1988) ${ }^{26}$.

22 Por. Jakie rezultaty po ubiegłorocznym spotkaniu Franciszka z Cyrylem?, https://ekai.pl/ jakie-rezultaty-po-ubieglorocznym-spotkaniu-franciszka-z-cyrylem/ (15.05.2018).

${ }^{23}$ Por. Plan pour la mise en route du dialogue théologique entre l'Église catholique et l'Église orthodoxe, „Proche-Orient Chrétien” 51 (2001) fasc. 1-2, s. 143-149. Na ten temat zob. W. Hryniewicz, Kościoły siostrzane: dialog katolicko-prawosławny 1980-1991, Warszawa 1993 [dalej: KoS], s. 28; D. Salachas, Il dialogo teologico ufficiale tra la chiesa cattolico-romana e la chiesa ortodossa. Iter e documentazione, Bari 1994, s. 25-30.

24 Por. Międzynarodowa Komisja Mieszana do Dialogu Teologicznego między Kościołem rzymskokatolickim a Kościołem prawosławnym, Misterium Kościoła i Eucharystii w świetle tajemnicy Trójcy Świętej (Monachium, 1982), w: KoS, s. 35-44.

25 Por. Międzynarodowa Komisja Mieszana do Dialogu Teologicznego między Kościołem rzymskokatolickim a Kościołem prawosławnym, Wiara, sakramenty i jedność Kościoła (Bari 1987), w: KoS, s. 45-55.

26 Por. Międzynarodowa Komisja Mieszana do Dialogu Teologicznego między Kościołem rzymskokatolickim a Kościołem prawosławnym, Sakrament kapłaństwa w sakramentalnej 
W drugiej fazie (1990-2006) katolicko-prawosławny dialog teologiczny zdominowała problematyka uniatyzmu i prozelityzmu. W kontekście przemian polityczno-społecznych w Europie Środkowo-Wschodniej i odradzania się Kościoła katolickiego obrządku wschodniego na tym obszarze, doszło do licznych konfliktów między prawosławnymi i katolikami obrząaku wschodniego, które doprowadziły do poważnego kryzysu w relacjach katolicko-prawosławnych. W związku z tym Komisja Mieszana wypracowała dwa teksty: Dokument o uniatyzmie i prozelityzmie (Freising, 1990 ${ }^{27}$ oraz Uniatyzm, metoda unijna przesztości, a obecne poszukiwanie petnej wspólnoty (Balamand, 1993) ${ }^{28}$. Mimo wyraźnego zdystansowania się obydwu stron dialogu od uniatyzmu i mimo oficjalnego wyrzeczenia się prozelityzmu, nie udało się przezwyciężyć kryzysu w relacjach między katolikami i prawosławnymi. Wszystko to doprowadziło do zawieszenia w latach 1993-2006 teologicznego dialogu katolicko-prawosławnego ${ }^{29}$. Trzecia faza dialogu, zapoczątkowana podczas spotkania Komisji w Belgradzie w 2006 roku, koncentruje się wokół zagadnienia soborowości (synodalności) i autorytetu w Kościele. W toku wspólnej refleksji wypracowano dotąd dwa dokumenty: Eklezjologiczne i kanoniczne konsekwencje sakramentalnej natury Kościoła. „Communio", soborowość i autorytet w Kościele (Rawenna, 2007) oraz Synodalność i prymat w Pierwszym Tysiacleciu: ku wspólnemu rozumieniu synodalności i prymatu w służbie jedności Kościoła $\left(\right.$ Chieti, 2016) ${ }^{30}$.

strukturze Kościoła ze szczególnym uwzględnieniem znaczenia sukcesji apostolskiej dla uświęcenia i jedności Ludu Bożego (Uusi Valamo, 1988), w: KoS, s. 56-66.

27 Por. Międzynarodowa Komisja Mieszana do Dialogu Teologicznego między Kościołem rzymskokatolickim a Kościołem prawosławnym, Dokument o uniatyzmie i prozelityzmie (Freising, 1990), w: KoS, s. 67-69.

28 Por. Międzynarodowa Komisja Mieszana do Dialogu Teologicznego między Kościołem rzymskokatolickim a Kościołem prawosławnym, Uniatyzm, metoda unijna przeszłości, a obecne poszukiwanie petnej wspólnoty (Balamand, 1993), „Studia i Dokumenty Ekumeniczne” 10 (1994) nr 2, s. 77-82.

29 Na temat historii kryzysu w dialogu rzymskokatolicko-prawosławnym w latach 90. XX wieku, zwłaszcza w relacjach między Moskwą i Rzymem zob. A. Cazzago, Giovanni Paolo II e Alessio II. Un incontro per sperare, „Communio” (wyd. wł.) 2003 nr 190-191, s. 111-150. ${ }^{30}$ Por. Commission internationale mixte pour le dialogue théologique entre l'Église catholique romaine et l'Église orthodoxe, Synodalité et primauté au premier millénaire: vers une compréhension commune au service de l'unité de l'Église (Chieti, 21 septembre 2016), „Istina” 
Wypracowane teksty stanowią niewątpliwie duże osiągnięcie katolicko-prawosławnego dialogu teologicznego. Z drugiej strony należy zauważyć, że wspólne uzgodnienia nie znalazły dotąd realnej i dostatecznej recepcji w życiu obydwu Kościołów. W rezultacie można odnieść wrażenie, że deklaracje na najwyższym szczeblu dialogu o ,prawie całkowitej jedności” między „Kościołami siostrzanymi” mają jedynie charakter werbalny, gesty potwierdzające jedność są gestami spektakularnymi, a różnice historyczno-doktrynalne po obu stronach pozostają nadal różnicami w pełni realnymi ${ }^{31}$.

\section{Uwarunkowania początków dialogu}

Problemy, które warunkują oficjalny dialog katolicko-prawosławny, nie zrodziły się nagle. W pewnym stopniu były one obecne w relacjach między dwoma Kościołami od samego początku dialogu, ale nie poświęcono im należytej uwagi ${ }^{32}$.

\section{1. „Niesymetryczność” podmiotów}

Pierwszym znaczącym ograniczeniem katolicko-prawosławnego dialogu teologicznego jest „niesymetryczność” podmiotów (partnerów) zaangażowanych w dialog, która wynika z odmiennych struktur katolicyzmu i prawosławia.

Podczas gdy katolicyzm ma scentralizowane struktury organizacyjne, to prawosławie składa się z wielu samodzielnych (autokefalicznych) Kościołów lokalnych, związanych ze sobą jednością wiary, sakramentów

62 (2017) nr 1, s. 97-103. W związku z tym zob. Z. Glaeser, Teologiczny dialog rzymskokatolicko-prawosławny: stan i perspektywy, w: Ekumenizm doktrynalny: schyłek czy nowy poczatek?, red. T. Kałużny, Z.J. Kijas, Kraków 2018, s. 91-117.

31 Por. H. Paprocki, Dialog ekumeniczny z punktu widzenia prawosławnego, w: Od konfrontacji do dialogu. Doświadczenia Kościoła w XX wieku, red. V. Kmiecik, A. Czaja, K. Kowalik, Lublin 2003, s. 302; S. Manna, Quale la recezione effettiva seguita ai dialoghi della Commissione mista cattolico-ortodossa?, „Nicolaus” 20 (1993) nr 2, s. 55-76.

32 Por. Plan pour la mise en route du dialogue..., dz. cyt.; B. Petrà, Sul dialogo teologico ufficiale tra ortodossia e cattolicesimo, „Archivio Teologico Torinese” 11 (2005) nr 2, s. 293. 
i zasad kanonicznych. Taka sytuacja znajduje swoje odzwierciedlenie w dialogu katolicko-prawosławnym, gdzie strona katolicka jako jeden podmiot (Kościół katolicki) spotyka się z wieloma podmiotami ze strony prawosławnej (liczne Kościoły autokefaliczne). W ten sposób prawosławni uczestnicy Międzynarodowej Komisji Mieszanej do Dialogu Teologicznego między Kościołem rzymskokatolickim i Kościołem prawosławnym nie stanowią jednolitej delegacji prawosławnej, ale sumę przedstawicieli różnych Kościołów prawosławnych. Istotnie, wśród Kościołów prawosławnych można dostrzec odmienne podejście do niektórych kwestii, co powoduje napięcia między nimi, jak również zróżnicowane zainteresowanie i zaangażowanie w dialog katolicko-prawosławny ${ }^{33}$.

\subsection{Cel dialogu}

Celem katolicko-prawosławnego dialogu teologicznego - jak czytamy w pierwszej części Planu - jest „przywrócenie pełnej wspólnoty (komunii)" między Kościołem rzymskokatolickim a Kościołem prawosławnym. Ta wspólnota „oparta na jedności wiary, zgodnie z doświadczeniem i wspólną tradycją starożytnego Kościoła, znajdzie swój wyraz we wspólnej celebracji Świętej Eucharystii”34.

Tak określony cel katolicko-prawosławnego dialogu spotkał się od początku z podwójną interpretacją. W oczach katolików jedność wiary między Kościołem rzymskokatolickim a Kościołem prawosławnym istnieje

33 Por. B. Petrà, Sul dialogo teologico ufficiale..., dz. cyt., s. 295; R. Hotz, Kościół wschodni a Kościół zachodni..., dz. cyt., s. 66-67. Świadczą o tym między innymi częste nieobecności wielu delegacji prawosławnych w sesjach plenarnych Komisji Mieszanej. Tak np. spośród 14 (a od 1993 - 15) Kościołów prawosławnych uczestniczących w omawianym dialogu w czasie obrad Komisji Mieszanej zabrakło przedstawicieli odpowiednio: w Bari (1986) 8 Kościołów (Jerozolimy, Rosji, Serbii, Gruzji, Grecji, Cypru, Polski, Czechosłowacji); w Bari 1987) - 3 Kościołów (Rosji, Gruzji, Czechosłowacji); Valamo (1988) - 2 (Antiochii, Serbii); Freising (1990) - 6 Kościołów (Antiochii, Jerozolimy, Serbii, Bułgarii, Polski, Czechosłowacji); Balamand (1993) - 5 (Jerozolimy, Serbii, Bułgarii, Gruzji, Grecji); Baltimore (2000) - 5 (Jerozolimy, Serbii, Bułgarii, Gruzji, Czech i Słowacji). Por. T. Kałużny, Prawosławie, w: Jan Paweł II, Encyklopedia dialogu i ekumenizmu, red. E. Sakowicz, Radom 2006, s. 384.

34 Plan pour la mise en route du dialogue..., dz. cyt., s. 143. 
już w tym, co istotne ${ }^{35}$. Dla prawosławnych fakt istnienia takiej jedności wiary nie jest sprawą oczywistą ${ }^{36}$. W związku z tym w rozumieniu katolików chodzi o przywrócenie pełnej wspólnoty między obydwoma Kościołami, ponieważ fundamentalna jedność wiary już między nimi istnieje. Natomiast według prawosławnych należy najpierw przywrócić (podstawową) jedność wiary, aby w ogóle można było mówić o jakiejś wspólnocie między prawosławnymi a katolikami. Tak więc katolicy bardziej optymistycznie postrzegają cel prezentowanego dialogu, podczas gdy dla prawosławnych jawi się on jako rzeczywistość bardziej odległa, trudna i złożona ${ }^{37}$.

W dialogu katolicko-prawosławnym istnieje też trudność - wynikająca z odmiennych koncepcji teologii - w określeniu tego, co istotne dla jedności wiary. Podczas gdy na Zachodzie przez teologię powszechnie rozumie się systematyczne studium naukowe prawd wiary chrześcijańskiej, to chrześcijański Wschód prezentuje pewną niechęć do ujmowania nauki wiary $\mathrm{w}$ formie spekulatywnych definicji oraz do czynienia rozróżnień pomiędzy elementami istotnymi i nieistotnymi w nauce wiary. Wszystkie elementy wiary - jak utrzymuje wielu autorów prawosławnych - są jednakowo konieczne i nie należy ich traktować osobno. Zaprzeczenie jednego $\mathrm{z}$ nich prowadzi do zaprzeczenia wszystkich ${ }^{38}$. Wynika stąd radykalny maksymalizm, silne ukierunkowanie na całość, prowadzące ku antytezie: ,wszystko albo nic” - ortodoksja lub brak orto-

35 Ojcowie Soboru Watykańskiego II w Dekrecie o ekumenizmie stwierdzają, że między katolikami i prawosławnymi istnieje jedność wiary w tym, co dotyczy podstawowych dogmatów chrześcijańskiej wiary o Trójcy Świętej i o Wcieleniu Syna Bożego. Por. UR, nr 14. Kościoły Wschodnie mimo odłączenia posiadają też prawdziwe sakramenty i sukcesją apostolską. Por. UR, nr 15.

${ }^{36}$ Por. J.-C. Larchet, Kościót - Ciało Chrystusa. Relacje między Kościołami, przekł. N. H. Aleksiejuk, Białystok 2016, s. 156-157; S. Manna, Quale la recezione effettiva..., dz. cyt., s. 69.

${ }_{37}$ Por. J. Famerée, Le dialogue catholique-orthodoxe. Bilan et perspectives, w: J. Famerée, Ecclésiologie et oecuménisme. Recueil d'études, Leuven-Paris-Bristol 2017, s. 412.

${ }^{38}$ W związku z tym arcybiskup Canterbury, Michael Ramsey, podczas wystąpienia na konferencji w Oxfordzie 10 marca 1962 roku zauważył, że prawosławni postrzegają wiarę chrześcijańską jako ikonę (obraz), na której zmiana jakiegokolwiek detalu niszczy symetrię całości. Podaję za: F.J. Thomson, Economy. An Examination of the Various Theories of Economy Held Within the Orthodox Church, With Special Reference to the Economical Recognition of the Validity of Non-orthodox Sacraments, „The Journal of Theological Studies” 16 (1965) nr 2, s. 381. 
doksji ${ }^{39}$.W rezultacie teologowie prawosławni napotykają dużą trudność w przyjęciu zaleceń zawartych w soborowym Dekrecie o ekumenizmie na temat „hierarchii prawd”, uprawnionej różnorodności sformułowań teologicznych, jak również kategorii niepełnej komunii (wspólnoty) ${ }^{40}$.

\subsection{Metoda dialogu}

Zgodnie z przyjętą w Planie metodą, teologiczny dialog katolicko-prawosławny rozpoczął się od zagadnień, które już teraz jednoczą obydwa Kościoła, aby następnie przejść do trudniejszych problemów, dzielących obydwie strony ${ }^{41}$.

Taka metoda dialogu podyktowana została nowym duchem ekumenicznym, który zaistniał między obydwoma Kościołami. Przyjęto założenie, które uznano za oczywiste, że przeszłość obydwu Kościołów po prostu bezpowrotnie minęła i jeśli chrześcijanie skoncentrują się na tym, co ich łączy, to rany podziałów zaczną się goić niemalże samoczynnie. W ten sposób uznano jednocześnie, iż istniejące rozbieżności między obydwoma Kościołami nie będą miały bezpośredniego wpływu na ten początkowy etap katolicko-prawosławnego dialogu. W tym to „duchu pozytywnym” w pierwszej fazie dialogu rozpoczęto zgłębianie pewnych aspektów eklezjologicznych i zagadnień związanych z sakramentami, co znalazło wyraz w pierwszych dokumentach dialogowych. W ten sposób w dialogu katolicko-prawosławnym - jak zauważył

39 Por. B. Petrà, Al cuore dell'Ortodossia. La teologia ortodossa e le nuove frontiere del dialogo tra Ortodossia e Cattolicesimo, „Rassegna di teologia” 41 (2000) nr 5, s. 746-747.

40 Por. UR, nr 11, 17; K.Ch. Felmy, Współczesna teologia prawosławna, przeł. H. Paprocki, Białystok 2005, s. 15-58; A. Siemianowski, Szkic zasad prawosławnej teologii, „W drodze” (1988) nr 8, s. 47-48; L. Žak, Il cammino ecumenico aperto..., dz. cyt., s. 469. Należy jednocześnie zauważyć, iż niektórzy autorzy prawosławni są świadomi potrzeby uwzględnienia wspomnianych rozróżnień czy kategorii w prowadzonych dialogach ekumenicznych. Por. np. Consulta ortodossa - cattolico-romana negli USA, Finalità, metodo e temi del dialogo (1982) cz. 2, w: Enchiridion Oecumenicum. Documenti del dialogo teologico interconfessionale, vol. 2: Dialoghi locali 1965-1987, a cura di G. Cereti, S.J. Voicu, Bologna 1988, s. 1653-1654; G. Larenzakis, The Unity of the Church as Koinonia. Some Reflections from an Orthodox Standpoint, „The Ecumenical Review" 45 (1993) nr 1, s. 71.

41 Por. Plan pour la mise en route du dialogue..., dz. cyt., II.1; B. Petrà, Sul dialogo teologico ufficiale..., dz. cyt., s. 293-294. 
prawosławny metropolita Chrysostomos (Konstantinidis) - można było rozwijać refleksję na temat Kościoła bez powiedzenia najpierw, który Kościół jest prawdziwy. Można było mówić na temat sakramentów bez wcześniejszego wyjaśnienia, gdzie są prawdziwe sakramenty i czy uznaje się sakramenty poza prawdziwym Kościołem ${ }^{42}$.

Dzisiaj, po wielu latach od tamtych wydarzeń, musimy jednak przyznać, że pozostawienie fundamentalnych kwestii, które dzielą obydwie strony, do rozpatrzenia w późniejszym czasie, nie ułatwiło katolicko-prawosławnego dialogu. Co więcej, przyjęta metoda dialogu szybko okazała się zawodna. Pomimo pozytywnej zmiany klimatu w relacjach katolicko-prawosławnych, nierozwiązane problemy i trudna przeszłość w relacjach katolicko-prawosławnych okazały się w pełni obecne w dialogu między dwoma Kościołami, niosąc z sobą poważne konsekwencje dla jego rozwoju. Tylko rozwiązanie kluczowych problemów eklezjologicznych - jak podkreślają teologowie prawosławni - może zapewnić realny postęp w teologicznym dialogu katolicko prawosławnym ${ }^{43}$.

\section{Kluczowe problemy natury eklezjologicznej}

Trudności w relacjach katolicko-prawosławnych uwidoczniły szereg problemów o charakterze eklezjologicznym. Należy do nich zaliczyć przede wszystkim problem wzajemnego uznania kościelnego statusu partnerów dialogu, rozumienie kategorii „Kościołów siostrzanych” oraz problem „uniatyzmu”.

\subsection{Kościelny status partnerów dialogu}

Ważnym elementem dialogu ekumenicznego jest postawa partnerstwa, która już na początku zakłada wzajemne uznanie kościelnego

42 Podaję za: D. Salachas, Il dialogo teologico ufficiale..., dz. cyt., s. 62. Por. B. Petrà, Sul dialogo teologico ufficiale..., dz. cyt., s. 294.

43 Por. J.-C. Larchet, Kościót - Ciało Chrystusa..., dz. cyt., s. 156. Na ten temat zob. B. Petrà, Sul dialogo teologico ufficiale..., dz. cyt., s. 295; L. Žak, Il cammino ecumenico aperto..., dz. cyt., s. 464 . 
statusu partnerów dialogu lub prowadzi do takiego uznania w toku dialogu. Niestety, w tej kwestii w katolicko-prawosławnym dialogu teologicznym można zauważyć brak wzajemności. Podczas gdy strona katolicka w pełni uznaje Kościół prawosławny za autentyczny Kościół, a sakramenty w nim sprawowane za ważne i skuteczne środki zbawienia, to strona prawosławna w żadnym oficjalnym dokumencie nie uznała eklezjalnego charakteru Kościoła katolickiego oraz ważności i zbawczej skuteczności katolickich sakramentów ${ }^{44}$. Stąd niektóre Kościoły prawosławne, a zwłaszcza niektórzy teologowie prawosławni, sprzeciwiają się przyznaniu Kościołowi katolickiemu takiego statusu. Kwestii tej nie zdołał rozwiązać w sposób definitywny Święty i Wielki Sobór Kościoła prawosławnego na Krecie (2016). W dokumencie Relacje Kościoła prawosławnego z pozostałym światem chrześcijańskim ${ }^{45}$ ojcowie Kreteńskiego Soboru dopuszczają jedynie możliwość posługiwania się historyczną nazwą „Kościołów” na określenie tych wspólnot ${ }^{46}$. Kwestia ta nie znalazła należytego rozwiązania także w dokumentach teologicznego dialogu katolicko-prawosławnego na forum światowym. W dokumencie z Monachium (1982) nie pojawiło się wyraźnie stwierdzenie o wzajemnym uznaniu przez obie strony swojej kościelności, ale jedynie wskazanie na potrzebę takiego uznania ${ }^{47}$. Dyskusja nad dokumentem z Bari (1987) na temat wiary i sakramentów pokazała, że wielu prawosławnych ma trudności z uznaniem ważności chrztu katolickiego ${ }^{48}$. W tej sytuacji należy uznać za nieuzasadnione, oderwane od rzeczywistości i będące wyrazem czysto życzeniowego myślenia ze strony niektórych ekumenistów katolickich i prawosławnych stwierdzenia, że obie strony dialogu uznają się

44 Por. J. Erickson, Reception into the Orthodox Church, „The Ecumenical Review” 54 (2002), s. 66-75; Иларион (Алфеев), Православно-католические отношения на современном этапе, https://mospat.ru/ru/2010/11/15/news30385/ (11.12.2017).

${ }_{45}$ Por. Saint et grand Concile de l'Église orthodoxe, Les relations de l'Église orthodoxe avec l'ensemble du monde chrétiens, dz. cyt.

46 Por. Saint et grand Concile de l'Église orthodoxe, Les relations de l'Église orthodoxe avec l'ensemble du monde chrétiens, dz. cyt., nr 6.

${ }_{47}$ Por. Międzynarodowa Komisja Mieszana do Dialogu Teologicznego między Kościołem rzymskokatolickim a Kościołem prawosławnym, Misterium Kościoła i Eucharystii w świetle tajemnicy Trójcy Świętej (Monachium, 1982), dz. cyt., III.3b.

48 Por. W. Hryniewicz, Kościoły siostrzane..., dz. cyt., s. 195-196. 
wzajemnie jako „prawdziwe Kościoły Chrystusa” czy też jako „Kościoły siostrzane" ${ }^{\prime 49}$.

\section{2. „Kościoły siostrzane”}

Pojęcie „Kościoły siostrzane” występuje wielokrotnie w dokumentach obydwu stron. Po raz pierwszy pojawiło się w liście patriarchy Athenagorasa z 12 kwietnia 1962 roku do kard. Augustyna Bei, a następnie w jego telegramie z 27 marca 1964 roku oraz w liście z 19 maja 1964 roku, skierowanym do papieża Pawła VI. Kategorię „Kościołów siostrzanych” przejął Sobór Watykański II w Dekrecie o ekumenizmie Unitatis redintegratio $(\mathrm{nr} 14)^{50}$. Posługiwali się nią metropolita Meliton w przemówieniu z 16 lutego 1965 roku do Pawła VI oraz kard. Johannes Willebrands w Stambule podczas posiedzenia komisji mieszanej przygotowującej deklarację o zniesieniu ekskomunik z 1054 roku. Określenie to jest użyte we wspólnym oświadczeniu papieża Pawła VI i patriarchy Atenagorasa I, ogłoszonym na zakończenie wizyty patriarchy w Rzymie w 1967 roku $^{51}$. Nawiązywał do niego często papież Jan Paweł II ${ }^{52}$. Omawiana kategoria zajmowała także ważne miejsce w teologicznym dialogu katolicko-prawosławnym $^{53}$. Tak na przykład autorzy dokumentu z Balamand (1993)

49 Por. Consulta ortodossa - cattolico-romana negli USA, Finalità, metodo e temi del dialogo (1982), dz. cyt., cz. 1 (s. 1654). Na ten temat zob. L. Žak, Il cammino ecumenico aperto..., dz. cyt., s. 463.

50 Por. UR, nr 14.

51 Por. Z. Glaeser, Istotne elementy eklezjologii „Kościołów siostrzanych”, w: „Kościoły siostrza$n e " w$ dialogu, red. Z. Glaeser, Opole 2002, s. 112-113.

52 Por. Jan Paweł II, Encyklika „Ut unum sint” o działalności ekumenicznej, 25 maja 1995, Watykan 1995, nr 56. W przemówieniu wygłoszonym podczas nabożeństwa ekumenicznego w prawosławnej katedrze św. Mikołaja w Białymstoku, 5 czerwca 1991 roku, Jan Paweł II między innymi stwierdził, że określenia „Kościoły siostrzane” nie należy traktować jako grzecznościowego zwrotu, ale jako fundamentalną kategorię eklezjologiczną. Por. Jan Paweł II, Przemówienie wygłoszone w czasie nabożeństwa ekumenicznego w prawosławnej katedrze św. Mikołaja (Białystok, 5 czerwca 1991), w: Ut unum. Dokumenty Kościoła katolickiego na temat ekumenizmu 1982-1998, red. S.C. Napiórkowski, K. Leśniewski, J. Leśniewska, Lublin 2000 [dalej: UU], s. 577.

53 Międzynarodowa Komisja Mieszana do Dialogu Teologicznego między Kościołem Rzymskokatolickim i Kościołem Prawosławnym, Uniatyzm, metoda unijna przyszłości a obecne poszukiwanie petnej wspólnoty (Balamand, 1993), dz. cyt., nr 12 i 14; Response of the Orthodox-Roman Catholic Consultation in the United States to the Joint International Commission for Theological 
wyraźnie stwierdzają, że „Kościół katolicki i Kościół prawosławny uznają się wzajemnie jako Kościoły siostrzane..." ${ }^{54}$.

Z czasem zaczęły się jednak zarysowywać - zarówno po stronie katolickiej, jak i prawosławnej - narastające wahania i trudności wokół idei Kościołów siostrzanych. Wielu prawosławnych teologów uważa, że termin „Kościoły siostrzane” może być stosowany jedynie w odniesieniu do poszczególnych Kościołów prawosławnych, które podzielają tę samą wiarę apostolską. Kościół prawosławny i Kościół rzymskokatolicki - jak podkreślają - nie wyznają jeszcze tej samej wiary. Trudności strony prawosławnej w tym względzie wynikają także z odmiennej eklezjologii, która znajduje się u podstaw rzymskokatolickiego rozumienia pojęcia „Kościoły siostrzane”. Podczas gdy rzymscy katolicy posługują się tym wyrażeniem dla określenia bratnich związków między Kościołami partykularnymi, zgromadzonymi wokół swoich biskupów i pozostającymi w jedności z Biskupem Rzymu, to prawosławni używają tego terminu w kontekście struktury kościelnej patriarchatu, w której relacje między Kościołami lokalnymi są zorganizowane według zasady „ojcostwa” („starszeństwa”) kościelnego. Prawosławni są też świadomi, że Kościół rzymskokatolicki nie zamierza uważać siebie za część struktury patriarchalnej. To odrzucenie struktury patriarchalnej postrzegają jednocześnie jako przeciwstawienie się relacjom międzykościelnym zdolnym do zachowania właściwej autonomii poszczególnych Kościołów lokalnych, zorganizowanych zgodnie z systemem patriarchalnym ${ }^{55}$. W rezultacie hierarchowie i teologowie prawosławni są dzisiaj wyjątkowo ostrożni

Dialogue Between the Orthodox Church and Roman Catholic Church Regarding the Balamand Document (dated June 23, 1993): "Uniatism, Method of Union of the Past, and the Present Search for Full Communion" (Brighton, MA, 1994), nr 12, w: The Quest for Unity: Orthodox and Catholics in Dialogue. Documents of the Joint International Commission and Official Dialogues in the United States 1965-1995, ed. J. Borelli, J.H. Erickson, New York-Washington 1996, s. 188.

54 Międzynarodowa Komisja Mieszana do Dialogu Teologicznego między Kościołem Rzymskokatolickim i Kościołem Prawosławnym, Uniatyzm, metoda unijna przyszłości a obecne poszukiwanie petnej wspólnoty (Balamand, 1993), dz. cyt., nr 12. Przypomnieli o tym Jan Paweł II i Bartłomiej I we wspólnej deklaracji, podpisanej 29 czerwca 1995 roku w Watykanie. Por. Wspólna deklaracja Papieża Jana Pawła II i Patriarchy Ekumenicznego Bartłomieja I, 29 czerwca 1995 r., nr 2, w: UU, s. 363.

55 Por. L. Žak, Il cammino ecumenico aperto..., dz. cyt., s. 454-456. 
w posługiwaniu się tym terminem w kontekście relacji z Rzymem, a niektórzy wprost kwestionują taką możliwośćs ${ }^{56}$. Nieuznanie przez grecką hierarchię prawosławną Kościoła katolickiego za Kościół siostrzany, a tym samym odmowa uznania ważności sprawowanych w nim sakramentów, była jedną z głównych przyczyn odrzucenia dokumentu z Balamand przez Kościół grecki w 1994 roku $^{57}$.

Po stronie katolickiej pewną powściągliwość w odniesieniu do pojęcia „Kościoły siostrzane” wyraziła Kongregacja Nauki Wiary w Liście o niektórych aspektach Kościoła jako komunii $(1992)^{58}$ oraz w Nocie na temat pojęcia „Kościoły siostrzane” (2000) ${ }^{59}$. W pierwszym z nich określenie „Kościoły siostrzane" traktowane jest raczej jako zwrot grzecznościowy, co zdaje się kontrastować z wizją Jana Pawła II, który wyraźnie podkreśla teologiczną wartość tego określenia ${ }^{60}$. W Nocie Kongregacja precyzuje, iż w znaczeniu ścisłym „Kościołami siostrzanymi” są wyłącznie Kościoły partykularne lub ich zgrupowania (np. patriarchaty i metropolie) między sobą. Tak rozumiany termin „Kościoły siostrzane” może się odnosić również do Kościoła rzymskiego, ale wyłącznie jako Kościoła lokalnego. Kościół uniwersalny zatem, jako jeden, święty, katolicki i apostolski, nie może

56 Tak np. Synodalna Komisja Teologiczna Patriarchatu Moskiewskiego na posiedzeniu 18 kwietnia 1997 roku uznała, że odwołanie się w dokumencie z Balamand (1993) do wyrażenia „Kościoły siostrzane” było podyktowane „raczej względami emocjonalnymi niż dogmatycznymi, w stylu ateistycznej publikacji okresu sowieckiego". Комментарий Синодалной Богословской Комисси к документам диалога между РПЦ МП и РКЦ, http://www.ortho-hetero.ru/index.php/doc-ecum/408 (12.04.2018). Por. H. Paprocki, Kościoły nie całkiem siostrzane, „Więź” 26 (1993) nr 7, s. 168; W. Hryniewicz, Kościoły mniej siostrzane? Wokół dokumentów Kongregacji Nauki Wiary, „Więź” 34 (2001) nr 2, s. 55-57.

57 Рог. Иларион (Алфеев), Православно-католические отношения..., dz. суt.; W. Hryniewicz, Kościoły mniej siostrzane..., dz. cyt., s. 54.

58 Por. Kongregacja Nauki Wiary, List „Communionis notio” o niektórych aspektach Kościoła pojętego jako komunia, 28 maja 1992, w: W trosce o petnię wiary. Dokumenty Kongregacji Nauki Wiary 1966-1994, red. i tłum. J. Królikowski, Z. Zimowski, Tarnów 2010, s. 470-483.

${ }_{59}$ Por. Kongregacja Nauki Wiary, Nota na temat właściwego używania pojęcia „Kościoły siostrzane”, 30 czerwca 2000, „Studia i Dokumenty Ekumeniczne” 17 (2001) nr 1, s. 91-94.

60 Por. Kongregacja Nauki Wiary, List „Communionis notio”..., dz. cyt., nr 17. Znamienne, że pojęcie „Kościoły siostrzane” nie pojawia się w ogóle w nowym Dyrektorium ekumenicznym Kościoła rzymskokatolickiego z 1993 roku. Por. Papieska Rada do Spraw Jedności Chrześcijan, Dyrektorium w sprawie realizacji zasad i norm dotyczacych ekumenizmu, 25 marca 1993, w: UU, s. 30-101; W. Hryniewicz, Kościoły mniej siostrzane..., dz. cyt., s. 48-49. 
być nazywany siostrą, gdyż jest matką wszystkich Kościołów partykularnych. Ponadto termin ten może być stosowany wyłącznie do tych wspólnot kościelnych, które zachowały ważny episkopat (sukcesja apostolska) i ważną Eucharystię. Odnosi się zatem do partykularnych Kościołów prawosławnych, nie zaś do Wspólnot protestanckich i anglikańskich ${ }^{61}$.

Wszystko to wskazuje, że założenia związane z odwołaniem się do pojęcia „Kościołów siostrzanych” w teologicznym dialogu katolicko-prawosławnym nie odpowiadały rzeczywistym przekonaniom zarówno strony katolickiej, jak i prawosławnej ${ }^{62}$.

\subsection{Problem „uniatyzmu”}

Trudności w dialogu katolicko-prawosławnym wynikają również z oskarżeń Kościoła katolickiego o popieranie uniatyzmu, czyli powrotu do unii jako sposobu osiągnięcia jedności chrześcijan. Dla strony prawosławnej uniajako metoda przyszłej jedności jest nie do przyjęcia, podobnie zresztą jak dla strony katolickiej. Jednak część prawosławnych teologów domaga się również zniesienia efektów zawartych unii, czyli katolickich Kościołów wschodnich, widząc w samym ich istnieniu wyraz uniatyzmu, prozelityzmu i ekspansji Kościoła katolickiego na prawosławne

61 Por. Kongregacja Nauki Wiary, Nota na temat właściwego używania pojęcia „Kościoły siostrzane", 30 czerwca 2000, dz. cyt., nr 3-12; W. Hryniewicz, Kościoły mniej siostrzane..., dz. cyt., s. 58-60. Odnosząc się do stanowiska katolickiego, wyrażonego w analizowanej części Noty, Eleni Fotiju zauważa: „Czy nie widać tutaj wyraźnie, że nasze zachodnie posługiwanie się określeniem «katolicki» jest co najmniej nieprecyzyjne? Jeżeli zarówno Kościoły katolickie, jak i niekatolickie mogą być uznawane za siostry względem siebie, byleby tylko uważały się za partykularne, czyli innymi słowy: lokalne, to należy postawić pytanie, czy kategoria owej siostrzaności jest bardziej zakorzeniona w ich lokalności, niż w ich indywidualnym udziale w tej katolickości, jaką wyznajemy w Credo? Jaka jest bowiem relacja tego Kościoła katolickiego, który uznajemy za matkę wszystkich Kościołów partykularnych, do partykularnego Kościoła Rzymu, któremu przysługuje miano „siostry” (por. nr 10 i 11)? Czyżby ten macierzyński wymiar Kościoła sprowadzał się do jurysdykcyjnej władzy papieża i uprawnień Kurii Rzymskiej?" ( E. Fotiju, Gdy lęk silniejszy niż nadzieja..., dz. cyt., s. 234-235).

62 Por. M. Stavrou, Les "ambigua" du Document de Balamand pour sa réception du côté orthodoxe, w: Comité mixte catholique-orthodoxe en France, Catholiques et Orthodoxes: les enjeux de l'uniatisme. Dans le sillage de Balamand, Paris 2004, s. 327; B. Petrà, Sul dialogo teologico ufficiale..., dz. cyt., s. 298. 
„terytorium kanoniczne”. Zastrzeżenia strony prawosławnej w sprawie katolickich Kościołów wschodnich były obecne z różną intensywnością od początku katolicko-prawosławnego dialogu teologicznego. Przybrały one na sile pod koniec lat 80 . XX wieku, w kontekście odradzania się katolickich Kościołów wschodnich po latach prześladowań. W ożywieniu ich działalności strona prawosławna dopatrywała się niebezpieczeństwa nowego „uniatyzmu"63.

Próbę wyjaśnienia tego problemu podjęto w czasie sesji plenarnych Katolicko-Prawosławnej Komisji Mieszanej w Freising (1990) oraz w Balamand. Zasadnicze znaczenie w tej sprawie miał katolicko-prawosławny dokument z Balamand (1993) ${ }^{64}$. Autorzy tego tekstu wydają się kwestionować zarówno historyczną sensowność i wartość zawieranych unii, jak również ich eklezjologiczne uzasadnienie. Podkreślają, że działania unijne były nieskuteczne, ponieważ nie osiągnęły swojego celu, którym była jedność Kościoła. Wskazują wyłącznie na negatywne konsekwencje zawieranych unii. Wśród nich wymieniają: zerwanie wspólnoty z macierzystymi Kościołami wschodnimi, konflikty i cierpienia, ekskluzywizm soteriologiczny połączony z prozelityzmem, który nie jest do pogodzenia z eklezjologią Kościołów siostrzanych. Prowadzi to autorów dokumentu do odrzucenia uniatyzmu jako należącej do przeszłości metody zjednoczenia i modelu poszukiwanej jedności ${ }^{65}$. Autorzy dokumentu z Balamand zdają się jednak pomijać milczeniem podstawy teologiczne uniatyzmu, które stanowią o tym, że Kościoły te są unickimi, a nie prawosławnymi, tj. wspólnotę wiary z Kościołem katolickim i uznanie szczególnej roli Bisku-

63 Por. W. Kasper, Między Moskwa a Rzymem - teologiczne korzenie problemu, „Przegląd Powszechny” (2002) nr 6, s. 307-318; T. Kałużny, Prawosławie, dz. cyt., s. 378-382. „W tym odrodzeniu się i często postawie agresywnej unitów” - zauważa ks. Andrzej Kuźma - strona prawosławna „upatrywała podwójną grę” czy „dwulicowość” Kościoła rzymskokatolickiego. $\mathrm{Z}$ jednej strony był prowadzony dialog z prawosławnymi i poszukiwano drogi pojednania, z drugiej natomiast - jak uważano - Watykan wspierał unitów. Por. A. Kuźma, Międzynarodowy dialog teologiczny Kościoła prawosławnego z Kościołem rzymskokatolickim, „Elpis” 16 (2014), s. 16.

64 Por. Międzynarodowa Komisja Mieszana do Dialogu Teologicznego między Kościołem rzymskokatolickim a Kościołem prawosławnym, Uniatyzm, metoda unijna przeszłości..., dz. cyt.

65 Międzynarodowa Komisja Mieszana do Dialogu Teologicznego między Kościołem rzymskokatolickim i Kościołem prawosławnym, Uniatyzm, metoda unijna przyszłości, dz. cyt., nr 12. 
pa Rzymu. Poza tym w dzisiejszej ocenie unii oraz współczesnej działalności Kościołów unickich nie docenia się dostatecznie tożsamościowych czynników pozateologicznych: historycznych, narodowych czy politycznych, które w dialogu katolicko-prawosławnym na ten temat odgrywają doniosłą rolę. W dokumencie z Balamand przyznaje się wprawdzie katolickim Kościołom wschodnim prawo do istnienia i opieki nad swoimi wiernymi ${ }^{66}$. Można jednak zapytać: Jak w świetle wierności własnej tradycji powinno wyglądać ich istnienie, skoro działania grekokatolików zmierzające do podkreślenia własnej specyfiki oceniane są przez wielu współczesnych teologów prawosławnych negatywnie. W imię powodzenia katolicko-prawosławnego dialogu ekumenicznego pod adresem katolickich Kościołów wschodnich nadal wysuwany jest postulat „powrotu” do korzeni prawosławnych, czyli rezygnacji z własnej specyfiki ${ }^{67}$. Takie podejście do sprawy uniatyzmu ma też swój wpływ na trudny proces recepcji dokumentu z Balamand nie tylko w lokalnych Kościołach prawosławnych, ale także w Kościele katolickim ${ }^{68}$.

Podsumowując, można zauważyć, że w ostatnich dziesięcioleciach w dialogu katolicko-prawosławnym dokonał się niewątpliwie duży postęp wyrażający się w diametralnie odmiennej postawie wobec siebie obydwu stron w stosunku do tysiącletniej wrogości. Z drugiej strony w toku tego dialogu pojawiło się szereg trudności i problemów. Zasadnicze obszary i przyczyny tych trudności koncentrują się wokół rozbieżności w ocenie podziału, uwarunkowań historyczno-kulturowych, przyjętych u początku dialogu założeń, dotyczących zwłaszcza jego celu i metody oraz nierozwiązanych dotąd w relacjach obydwu stron podstawowych kwestii eklezjologicznych takich, jak: wzajemne uznanie

66 Międzynarodowa Komisja Mieszana do Dialogu Teologicznego między Kościołem rzymskokatolickim i Kościołem prawosławnym, Uniatyzm, metoda unijna przyszłości, dz. cyt., nr 16.

67 Por. M. Składanowski, Tożsamość wyznaniowa. Studium ekumeniczne, Lublin 2012, s. $252-$ 255. Postulat likwidacji Kościoła greckokatolickiego przez Rzym pojawił się także w toku katolicko-prawosławnego dialogu teologicznego. Por. W. Hryniewicz, Kościoły siostrzane..., dz. cyt., s. 240-241.

68 Por. B. Bourgine, La réception de la déclaration de Balamand, $\mathrm{w}$ : Comité mixte catholique-orthodoxe en France, Catholiques et Orthodoxes: les enjeux de l'uniatisme. Dans le sillage de Balamand, Paris 2004, s. 247-275; B. Petrà, Sul dialogo teologico ufficiale..., dz. cyt., s. 297. 
kościelnego statusu partnerów dialogu, rozumienie kategorii „Kościołów siostrzanych” i stosunek do kwestii „uniatyzmu”. W rezultacie katolicko-prawosławny dialog teologiczny okazuje się dialogiem trudnym. Istniejące trudności dialogowe nie muszą jednak prowadzić do zniechęcenia, ale wręcz przeciwnie - mogą stać się impulsem do pogłębienia i ożywienia katolicko-prawosławnego dialogu teologicznego. Pomocna dla takiego podejścia jest realistyczna ocena stanu jedności oraz obiektywnych różnic i trudności w relacjach między katolikami i prawosławnymi. Poza tym przed podjęciem kolejnych tematów w dialogu sprawą bardzo ważną pozostaje recepcja już przyjętych dokumentów dialogowych w życiu obydwu Kościołów. Tak długo bowiem, jak dialog ten nie przeniknie głębiej do świadomości ogółu wierzących po obu stronach, pozostanie on w dużym stopniu jedynie abstrakcyjnym i akademickim dyskursem, i co najwyżej będzie wyrazem dobrej woli lub „uprzejmości ekumenicznej" niektórych jego uczestników. 


\section{Summary}

Ku ekumenii realistycznej. W poszukiwaniu przyczyn trudności w katolicko-prawosławnym dialogu teologicznym

Celem niniejszego artykułu jest prezentacja ważniejszych przyczyn trudności w katolicko-prawosławnym dialogu teologicznym na forum światowym. Temat został rozwinięty w czterech częściach. Najpierw zwrócono uwagę na odmienną świadomość podziału w katolicyzmie i w prawosławiu. Następnie dokonano ogólnej prezentacji wybranych aspektów katolicko-prawosławnego „dialogu miłości” i „dialogu prawdy”. W trzeciej części omówiono uwarunkowania początków dialogu teologicznego między obydwoma Kościołami. W końcu odniesiono się do kluczowych problemów natury eklezjologicznej, które pojawiły się w toku dialogu, takich jak uznanie kościelnego statusu partnerów dialogu, rozumienie kategorii „Kościołów siostrzanych” i stosunek do kwestii „uniatyzmu”. Ostatecznie stwierdzono, że katolicko-prawosławny dialog teologiczny jest dialogiem trudnym. Istniejące trudności dialogowe nie muszą jednak prowadzić do zniechęcenia, ale wręcz przeciwnie - mogą stać się impulsem do pogłębienia i ożywienia katolickoprawosławnego dialogu teologicznego.

Słowa kluczowe: dialog ekumeniczny, Kościół rzymskokatolicki, Kościół prawosławny, ekumenizm, eklezjologia

Toward Realistic Ecumenism. Looking for the Causes of Difficulties in the Theological Dialogue between the Roman Catholic Church and the Orthodox Church

The aim of this article is to present the essential causes of the difficulties in the theological dialogue between the Roman Catholic Church and the Orthodox Church in the world. The topic has been dealt upon in four parts. First, the author is drawing the reader's attention to the fact that the awareness of the disunion differs in these two Churches. Next, the author is making a general presentation of selected aspects of the "dialogue of love" and the "dialogue of truth" between Roman Catholicism and Orthodoxy. In Part 3, the author is discussing the circumstances of the beginnings of the theological dialogue between them. At the end, he is referring to the key ecclesiological problems which appeared in the course of the dialogue such as accepting the ecclesial status of the dialogue partner, understanding the category of "Sister Churches", and attitude to the issue of "Uniatism". Finally, the author states that the theological Catholic-Orthodox dialogue is a difficult one. However, the existing difficulties in the dialogue do not have to lead to discouragement, but - quite the contrary - they may become 


\section{Tadeusz Kałużny SCJ}

an incentive to deepen and invigorate the theological dialogue the Roman Catholic Church and the Orthodox Church.

Keywords: ecumenical dialogue, Roman Catholic Church, Orthodox Church, ecumenism, ecclesiology

\section{Bibliografia}

Archijeriejskij Sobor Russkoj Prawosławnoj Cerkwi, Osnownyje principy otnoszenija Russkoj Prawosławnoj Cerkwi kinosławiju (2000), „Żurnał Moskowskoj Patriarchii” 2000 nr 10, s. 22-30.

Bourgine B., La réception de la déclaration de Balamand, w: Comité mixte catholique-orthodoxe en France, Catholiques et Orthodoxes: les enjeux de l'uniatisme. Dans le sillage de Balamand, Paris 2004, s. 247-275.

Brewe papieża Pawła VI „Ambulate in dilectione” ogłaszające wymazanie z pamięci i miejsca $w$ Kościele ekskomunik z 1054 roku (7 grudnia 1965), w: Jan Paweł II $w$ dialogu miłości z Kościołem Wschodnim, red. A. Polkowski, Warszawa 1984, s. 332-333.

Bujak J., Jedność na nowo odkrywana. Dialog katolicko-prawosławny w latach 1958-2000, Poznań 2001.

Burza w prawosławiu po historycznym spotkaniu, https://wiadomości.monasterujkowice.pl/?p=17699 (15.05.2018).

Cazzago A., Giovanni Paolo II e Alessio II. Un incontro per sperare, „Communio” (wyd. wł.) $2003 \mathrm{nr} 190-191$, s. 111-150.

Commission internationale mixte pour le dialogue théologique entre l'Église catholique romaine et l'Église orthodoxe, Synodalité et primauté au premier millénaire: vers une compréhension commune au service de l'unité de l'Église (Chieti, 21 septembre 2016), „Istina” 62 (2017) nr 1, s. 97-103.

Conciliorum Oecumenicorum Generaliumque Decretal, The Great Councils of the Orthodox Churches. Decisions and Synodika, ed. A. Melloni, Brepols 2016, s. 1253-1293 (Corpus Christianorum Oecumenicorum Generaliumque Decreta. Editio critica, IV.3).

Consulta ortodossa - cattolico-romana negli USA, Finalità, metodo e temi del dialogo (1982), w: Enchiridion Oecumenicum. Documenti del dialogo teologico interconfessionale, vol. 2: Dialoghi locali 1965-1987, a cura di G. Cereti, S.J. Voicu, Bologna 1988, s. $1652-1660$.

Erickson J., Reception into the Orthodox Church, „The Ecumenical Review” 54 (2002), s. 66-75.

Famerée J., Le dialogue catholique-orthodoxe. Bilan et perspectives, w: J. Famerée, Ecclésiologie et oecuménisme. Recueil d'études, Leuven-Paris-Bristol 2017, s. 407-422.

Felmy K.Ch., Wspótczesna teologia prawosławna, przeł. H. Paprocki, Białystok 2005.

Fotiju E., Gdy lęk silniejszy niż nadzieja..., w: Ekumeniczna odpowiedzialność na początku Trzeciego Tysiąclecia, red. G. Górka, S. Pawłowski, Lublin 2003, s. 215-235.

Glaeser Z., Istotne elementy eklezjologii „,Kościołów siostrzanych”, w: „Kościoły siostrza$n e " w$ dialogu, red. Z. Glaeser, Opole 2002, s. 109-124. 
Glaeser Z., Teologiczny dialog rzymskokatolicko-prawosławny: stan i perspektywy, w: Ekumenizm doktrynalny: schyłek czy nowy początek?, red. T. Kałużny, Z.J. Kijas, Kraków 2018, s. 91-117.

Hotz R., Kościót wschodni a Kościót zachodni. Dwie przeciwstawne perspektywy, „Communio" 13 (1993) nr 4, s. 65-75.

Hryniewicz H., Kościoły mniej siostrzane? Wokót dokumentów Kongregacji Nauki Wiary, „Więź” 34 (2001) nr 2, s. 46-60.

Hryniewicz W., Kościoły siostrzane: dialog katolicko-prawosławny 1980-1991, Warszawa 1993.

Iłarion(Ałfiejew), Prawosławno-katoliczeskije otnoszenija na sowriemiennom etapie, https://mospat.ru/ru/2010/11/15/news30385/ (11.12.2017).

Jakie rezultaty po ubiegłorocznym spotkaniu Franciszka z Cyrylem?, https://ekai.pl/ jakie-rezultaty-po-ubieglorocznym-spotkaniu-franciszka-z-cyrylem/ (15.05.2018).

Jan Pawet II w dialogu miłości z Kościołem Wschodnim, red. A. Polkowski, Warszawa 1984.

Jan Paweł II, Encyklika „Ut unum sint” o działalności ekumenicznej, 25 maja1995, Watykan 1995.

Jan Paweł II, Przemówienie wygłoszone w czasie nabożeństwa ekumenicznego w prawosławnej katedrze św. Mikołaja (Białystok, 5 czerwca 1991), w: Ut unum. Dokumenty Kościoła katolickiego na temat ekumenizmu 1982-1998, red. S.C. Napiórkowski, K. Leśniewski, J. Leśniewska, Lublin 2000, s. 576-578.

Jarco J., Stagnacja czy postęp? Dialog katolicko-prawosławny, „Życie i Myśl” 1972 nr 11-12, s. 59-70.

Kałużny T., Eklezjalna świadomość prawosławia a ekumenia, „Sympozjum” 11 (2007) nr 1, s. 51-66.

Kałużny T., Na drogach jedności. Dwustronne dialogi doktrynalne Kościoła rzymskokatolickiego na płaszczyźnie światowej, Kraków 2012.

Kałużny T., Prawosławie, w: Jan Paweł II, Encyklopedia dialogu i ekumenizmu, red. E. Sakowicz, Radom 2006, s. 365-388.

Kasper W., Między Moskwa a Rzymem - teologiczne korzenie problemu, „Przegląd Powszechny" (2002) nr 6, s. 307-318.

Kizeridis P., Il dialogo tra le Chiese cattolica e ortodossa dal 1920 all'abolizione delle scomuniche, Roma 1966.

Klinger J., O istocie prawosławia. Wybór pism, Warszawa 1983.

Kommientarij Sinodałnoj Bogosłowskoj Komissi k dokumentam diałoga mjeżdu RPC MP i RKC, http://www.ortho-hetero.ru/index.php/doc-ecum/408 (12.04.2018).

Kongregacja Nauki Wiary, List „Communionis notio” o niektórych aspektach Kościoła pojętego jako komunia (28 maja 1992), w: W trosce o petnię wiary. Dokumenty Kongregacji Nauki Wiary 1966-1994, red. i tłum. J. Królikowski, Z. Zimowski, Tarnów 2010, s. $470-483$.

Kongregacja Nauki Wiary, Nota na temat właściwego używania pojęcia „Kościoły siostrzane”(30 czerwca 2000), „Studia i Dokumenty Ekumeniczne” 17 (2001) nr 1, s. 91-94.

Kuźma A., Międzynarodowy dialog teologiczny Kościoła prawosławnego z Kościołem rzymskokatolickim, „Elpis” 16 (2014), s. 11-18. 
Larchet J.-C., Kościół - Ciało Chrystusa. Relacje między Kościołami, przekł. N. H. Aleksiejuk, Białystok 2016.

Larenzakis G., The Unity of the Church as Koinonia. Some Reflections from an Orthodox Standpoint, „The Ecumenical Review” 45 (1993) no 1, s. 69-71.

Manna S., Quale la recezione effettiva seguita ai dialoghi della Commissione mista cattolico-ortodossa?, „Nicolaus” 20 (1993) nr 2, s. 55-76.

Martano V., Athenagoras, il patriarca (1886-1972). Un cristiano fra crisi della coabitazione e utopia ecumenica, Bologna 1996.

Międzynarodowa Komisja Mieszana do Dialogu Teologicznego między Kościołem rzymskokatolickim a Kościołem prawosławnym, Misterium Kościoła i Eucharystii w świetle tajemnicy Trójcy Świętej (Monachium, 1982), w: W. Hryniewicz, Kościoły siostrzane: dialog katolicko-prawosławny 1980-1991, Warszawa 1993, s. 35-44.

Międzynarodowa Komisja Mieszana do Dialogu Teologicznego między Kościołem rzymskokatolickim a Kościołem prawosławnym, Wiara, sakramenty i jedność Kościoła (Bari, 1987), w: KoS, s. 45-55.

Międzynarodowa Komisja Mieszana do Dialogu Teologicznego między Kościołem rzymskokatolickim a Kościołem prawosławnym, Sakrament kapłaństwa w sakramentalnej strukturze Kościoła ze szczególnym uwzględnieniem znaczenia sukcesji apostolskiej dla uświęcenia i jedności Ludu Bożego (Uusi Valamo, 1988), w: KoS, s. 56-66.

Międzynarodowa Komisja Mieszana do Dialogu Teologicznego między Kościołem rzymskokatolickim a Kościołem prawosławnym, Dokument o uniatyzmie i prozelityzmie (Freising, 1990), w: KoS, s. 67-69.

Międzynarodowa Komisja Mieszana do Dialogu Teologicznego między Kościołem rzymskokatolickim a Kościołem prawosławnym, Uniatyzm, metoda unijna przeszłości, a obecne poszukiwanie pełnej wspólnoty (Balamand, 1993), „Studia i Dokumenty Ekumeniczne" 10 (1994) nr 2, s. 77-82.

Ogickij D.P., Kozłow M., Prawosławije i zapadnoje christianstwo. Uczebnoje posobije dla duchownych sieminarij i duchownych ucziliszcz, Moskwa 1999.

Papieska Rada do Spraw Jedności Chrześcijan, Dyrektorium w sprawie realizacji zasad i norm dotyczacych ekumenizmu (25 marca 1993), w: UU, s. 30-101.

Paprocki H., Dialog ekumeniczny z punktu widzenia prawosławnego, w: Od konfrontacji do dialogu. Doświadczenia Kościoła w XX wieku, red. V. Kmiecik, A. Czaja, K. Kowalik, Lublin 2003, s. 301-306.

Paprocki H., Kościoły nie całkiem siostrzane, „Więź” 26 (1993) nr 7, s. 168-171.

Petrà B., Al cuore dell'Ortodossia. La teologia ortodossa e le nuove frontiere del dialogo tra Ortodossia e Cattolicesimo, „Rassegna di teologia” 41 (2000) nr 5, s. 737-748.

Petrà B., Sul dialogo teologico ufficiale tra ortodossia e cattolicesimo, „Archivio Teologico Torinese" 11 (2005) nr 2, s. 283-310.

Plan pour la mise en route du dialogue théologique entre l'Église catholique et l'Église orthodoxe, „Proche-Orient Chrétien” 51 (2001) fasc. 1-2, s. 143-149.

Response of the Orthodox-Roman Catholic Consultation in the United States to the Joint International Commission for Theological Dialogue Between the Orthodox Church and Roman Catholic Church Regarding the Balamand Document (dated June 23, 1993): „Uniatism, 
Method of Union of the Past, and the Present Search for Full Communion" (Brighton, MA, 1994), w: The Quest for Unity: Orthodox and Catholics in Dialogue. Documents of the Joint International Commission and Official Dialogues in the United States 1965-1995, ed. J. Borelli, J.H. Erickson, New York-Washington 1996, s. 184-190.

Saint et Grand Concile de l'Église orthodoxe, Les relations de l'Église orthodoxe avec l'ensemble du monde chrétiens [Crète, 2016], w: The Great Councils of the Orthodox Churches. Decisions and Synodika, ed. A. Melloni, Brepols 2016, s. 1253-1293 (Corpus Christianorum Conciliorum Oecumenicorum Generaliumque Decreta. Editio critica, IV. 3).

Salachas D., Il dialogo teologico ufficiale tra la chiesa cattolico-romana e la chiesa ortodossa. Iter e documentazione, Bari 1994.

Siemianowski A., Szkic zasad prawostawnej teologii, „W drodze” (1988) nr 8, s. 47-52.

Składanowski M., Tożsamość wyznaniowa. Studium ekumeniczne, Lublin 2012.

Sobór Watykański II, Dekret o ekumenizmie „Unitatis redintegratio” (21 listopada 1964), w: UU, s. 11-26.

Stavrou M., Les «ambigua» du Document de Balamand pour sa réception du côté orthodoxe, w: Comité mixte catholique-orthodoxe en France, Catholiques et Orthodoxes: les enjeux de l'uniatisme. Dans le sillage de Balamand, Paris 2004, s. 323-342.

Thomson F.J., Economy. An Examination of the Various Theories of Economy Held Within the Orthodox Church, With Special Reference to the Economical Recognition of the Validity of Non-orthodox Sacraments, „The Journal of Theological Studies” 16 (1965) no 2, s. $368-420$.

"Tomos" patriarchy, w którym patriarcha Athenagoras I i zgromadzony z nim synod ogłaszaja wymazanie z pamięci i miejsca w Kościele ekskomunikz 1054 r. (Fanar, 7 grudnia 1965), w: JPwD, s. 334-335.

Ut unum. Dokumenty Kościoła katolickiego na temat ekumenizmu 1982-1998, red. S. C. Napiórkowski, K. Leśniewski, J. Leśniewska, Lublin 2000.

Wspólna Deklaracja papieża Franciszka i patriarchy Cyryla, Hawana (Kuba), 12 lutego 2016 r., https://opoka.org.pl/biblioteka/W/WP/franciszek_i/inne/deklaracja-hawana_12022016.html (14.06.2018).

Wspólna deklaracja papieża Pawła VI i patriarchy Atenagorasa I zawierająca decyzję wymazania z pamięci i miejsca w Kościele sentencji ekskomunik z 1054 roku (Fanar, 7 grudnia 1965), w: JPwD, s. 330-331.

Wspólna deklaracja Papieża Jana Pawła II i Patriarchy Ekumenicznego Bartłomieja I, 29 czerwca 1995 r., w: UU, s. 362-364.

Zajawlenije Stużby komunikacji OWCS o wstrecze Patpiarcha Maskowskowo i wsieja Rusi Kirilla i Papy Rimskowo Franciska (15.04.2016), https://mospat.ru/ru/2016/04/15/ new130222 (15.05.2018).

Žak L., Il cammino ecumenico aperto da „Unitas redintegratio" tra difficoltà e speranze: in dialogo con l'ortodossia, „Lateranum” 81 (2015) nr 2, s. 443-470. 